\title{
ANTIBIOTIC INHIBITION OF PROTEASE PRODUCTION BY PSEUDOMONAS AERUGINOSA
}

\author{
A. M. Shibl and I. A. Al-Sowaygh \\ College of Pharmacy, University of Riyad, Riyad, Saudi Arabia
}

PSEUDOMONAS AERUGINOSA is an unusual gram-negative bacillus in that many of its pathogenic effects are believed to be caused by extracellular products (haemolysin, lecithinase, toxin and protease) and not by the so-called endotoxin moiety (Liu, Abe and Bates, 1961; Liu, 1974).

Previous results (Meinke et al., 1970; Homma et al., 1975; Gray and Kreger, 1979) indicate that $P$. aeruginosa protease may be important in the pathogenesis of pseudomonas pneumonia. Homma et al. (1975) observed that the sera of patients contained elevated titres of antibody to pseudomonas protease. Meinke et al. (1970) reported that intranasal administration of $P$. aeruginosa protease to mice produced focal and confluent haemorrhagic lung lesions, macroscopically identical to those seen in human patients (Shimizu et al., 1974). Gray and Kreger (1979) considered that protease was at least partially responsible for the lung damage in pseudomonas pneumonia.

Because of the possible pathogenic importance of pseudomonas protease we investigated the in-vitro ability of antibiotics, in concentrations too low to affect greatly the growth and survival of $P$. aeruginosa, to suppress extracellular protease production.

\section{MATERIALS AND METHODS}

Bacterial strain. P. aeruginosa strain SAR was isolated from a human pneumonia specimen at King Abdul Aziz University Hospital. It produced pyocyanin and was identified by the method of Buchanan and Gibbons (1974). This strain was the best producer of extracellular protease among 20 strains tested by the method described below.

Culture methods and sampling. The kinetics of growth and protease production were followed for $24 \mathrm{~h}$ in 250 - $\mathrm{ml}$ cultures in trypticase soy broth (TSB). The antibiotic solutions were added at the beginning of the experiment or at various times during incubation. The flasks were seeded with an overnight TSB culture grown at $37^{\circ} \mathrm{C}$ to give a final concentration of approximately $10^{5}$ viable organisms $/ \mathrm{ml}$, and were incubated at $37^{\circ} \mathrm{C}$ on an orbital shaker (Gallenkamp) at 140 r.p.m. Optical densities were obtained by removing aseptically $2-\mathrm{ml}$ volumes of culture and reading the optical density (OD) at $490 \mathrm{~nm}$ in a Beckman spectrophotometer 20. Culture supernates were obtained from these samples by centrifugation at $10000 \mathrm{~g}$ for $20 \mathrm{~min}$. The supernates were sterilised by filtration and then used for protease assay.

Assay of protease was by the method of Brown and Foster (1970) with agar containing $15 \%$ (v/v) sterile skimmed milk. In preliminary experiments, wells 4,9 and $12 \mathrm{~mm}$ in diameter were filled with serial twofold dilutions of supernate from a 24-h culture. The plates were maintained at room temperature for $48 \mathrm{~h}$. The wells 9 and $12 \mathrm{~mm}$ in diameter were equally satisfactory for detecting the smallest concentrations of protease. Wells $9 \mathrm{~mm}$ in diameter were used in all subsequent experiments. The titre was the highest dilution that produced clearing around the wells.

Test for DNA. The method of Burton (1956) was used.

Extraction of intracellular protease. Ethylenediamine tetraacetate-lysozyme spheroplasts of $P$. aeruginosa were obtained by a modification of the procedure of Birdsell and Cota-Robles (1967). Cells from 8- and 16-h cultures were extensively washed with $0 \cdot 1 \mathrm{M}$ Tris buffer, $p \mathrm{H} 8.0$ 
(Sigma Chemical Co., no. T3253). Washed cells, $0.5 \mathrm{mg}$ dry weight, were suspended in $10 \mathrm{ml}$ of the same Tris buffer. Lysozyme $50 \mu \mathrm{g} / \mathrm{ml}$ was added and the cells were incubated at room temperature for $15 \mathrm{~min}$. The osmotically fragile spheroplasts were then lysed by the addition of $1 \mathrm{ml}$ of cold distilled water. The resulting cellular extract was clarified by centrifuging at 10000 $g$ for $20 \mathrm{~min}$. to remove cellular debris, and sterilised by filtration.

\section{RESULTS}

Enzymic activity in control-culture supernate was detectable (fig. 1) at an early stage of growth and increased during the logarithmic phase, reaching a maximum of $256 \mathrm{units} / \mathrm{ml}$ at $16 \mathrm{~h}$. Fig. 1 also shows the corresponding results in a culture containing a subinhibitory concentration $(0.9 \mu \mathrm{g} / \mathrm{ml})$ of tetracycline. The antibiotic produced only a slight adverse affect on growth, but protease production was completely inhibited. Tests for cellular DNA in the culture medium indicated that the release of protease in the control culture was not the result of cell lysis. The concentration of the antibiotic used was shown in control assays to have no effect on the activity of preformed enzyme.

The effect of various concentrations of tetracycline on growth and protease production was studied. The results (fig. 2) show that $0.45 \mu \mathrm{g} / \mathrm{ml}$ produced a $50 \%$ inhibition of protease production; a concentration of $0.9 \mu \mathrm{g} / \mathrm{ml}$ was deemed optimal for producing protease inhibition.

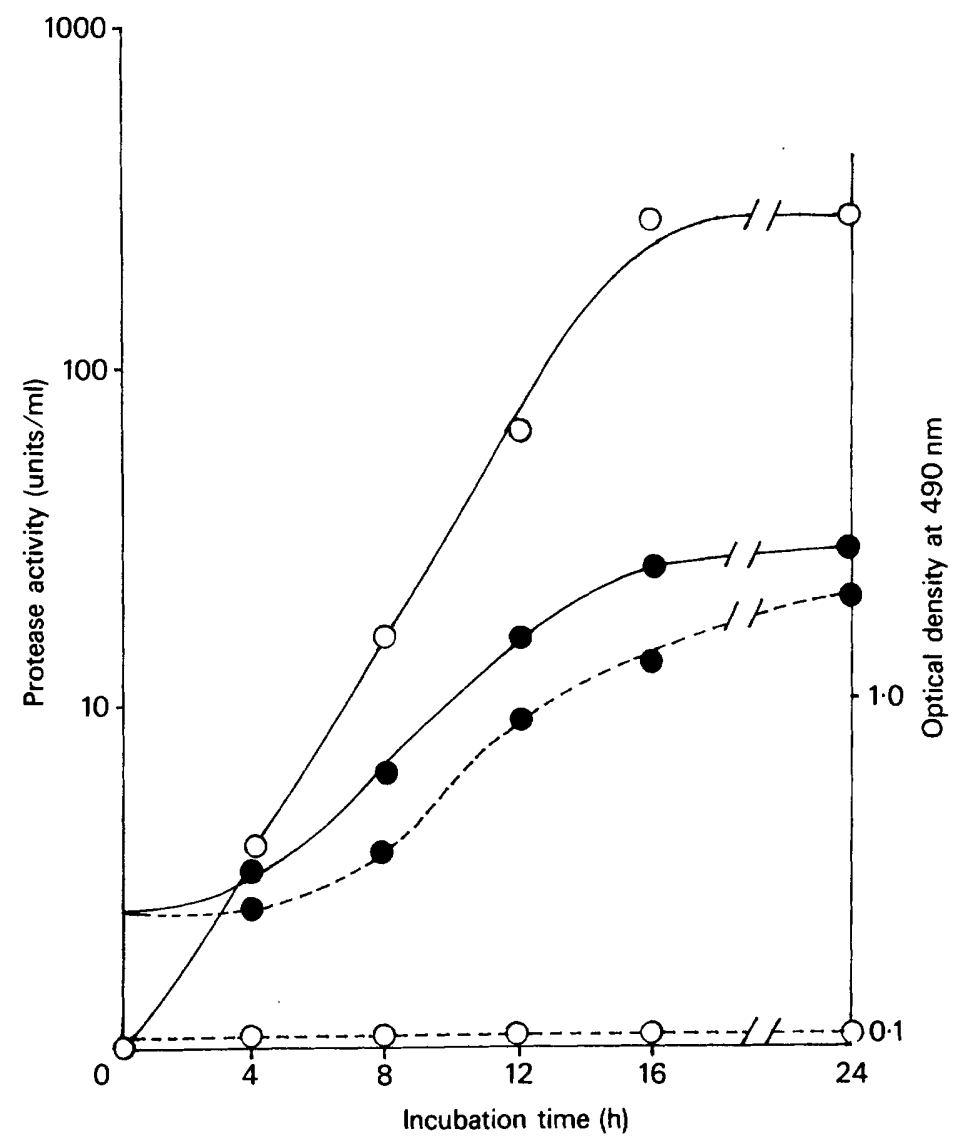

FIG. 1.-Extracellular protease $(\circ-0)$ and optical density $(\bullet-\bullet)$ in cultures of Pseudomonas aeruginosa with or without tetracycline, incubated for $24 \mathrm{~h} . \ldots--=$ Tetracycline-treated $(0.9 \mu \mathrm{g} / \mathrm{ml})$ culture; $=$ control culture. 


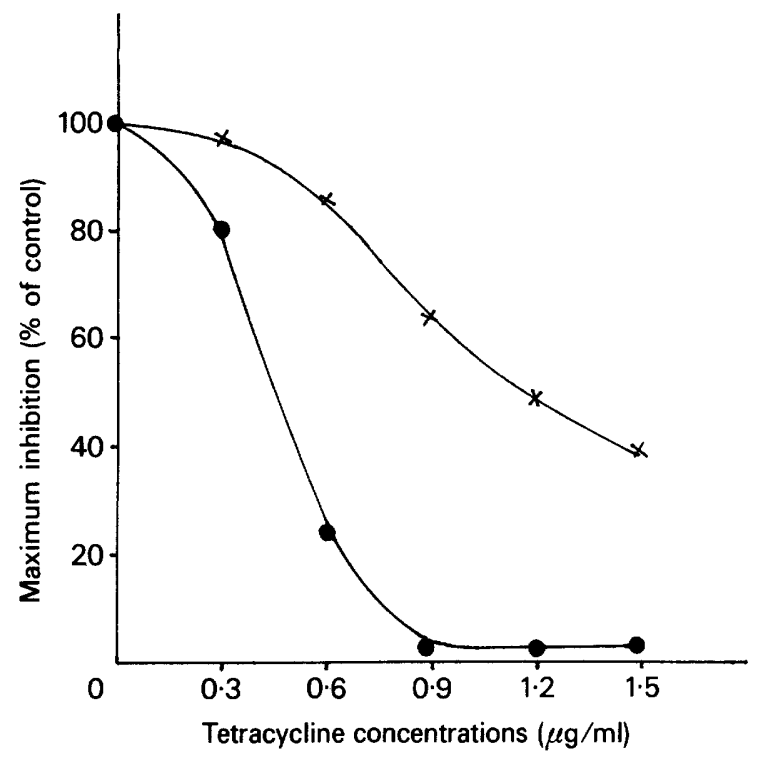

FIG. 2.-Differential inhibition of growth $(x)$ and protease production $(\bullet)$ by different concentrations of tetracycline, as shown in cultures incubated for $24 \mathrm{~h}$. Growth is expressed as optical density at $490 \mathrm{~nm}$; protease is expressed in units $/ \mathrm{ml}$.

When tetracycline $1.8 \mu \mathrm{g} / \mathrm{ml}$ was added $4,8,12$ and $16 \mathrm{~h}$ after the beginning of incubation, enzyme formation was halted. The fact that tetracycline was effective when added at an early stage of growth may suggest that it is related to some synthetic process rather than to modification of a preformed precursor.

The results suggested that tetracycline inhibited either the synthesis or the release of protease. After lysozyme treatment of washed tetracycline-treated cells protease could not be detected in the cell debris or in the supernate (table). This suggested that the effect of tetracycline was to inhibit protease synthesis.

TABLE

Effect of lysozyme on tetracycline-treated cells

\begin{tabular}{l|cc}
\hline $\begin{array}{c}\text { Material tested } \\
\text { (after lysozyme treatment) }\end{array}$ & $\begin{array}{c}\text { Protease (units/ml) in material derived } \\
\text { from culture aged }\end{array}$ \\
\cline { 2 - 3 } $\begin{array}{c}\text { Washed control cells: } \\
\text { extracellular fraction } \\
\text { intracellular fraction }\end{array}$ & 16 & $16 \mathrm{~h}$ \\
$\begin{array}{l}\text { Washed tetracycline-treated } \\
\text { cells: } \\
\text { extracellular fraction } \\
\text { intracellular fraction }\end{array}$ & $<4$ & 256 \\
\hline
\end{tabular}

Two other antibiotics were studied. Chloramphenicol $(0.7 \mu \mathrm{g} / \mathrm{ml})$ inhibited growth and protease production by $49 \%$ and $50 \%$ respectively. Polymyxin B $(1.5 \mu \mathrm{g} / \mathrm{ml})$ inhibited growth by $43 \%$ and protease production by $50 \%$. Thus these two antibiotics, unlike tetracycline, produced protease inhibition merely by virtue of growth inhibition. 


\section{Discussion}

Factors affecting the formation of extracellular protease in vitro are poorly understood, but carbon source, $p \mathrm{H}$, and oxygen tension are known to be of importance (Wretlind and Kronevi, 1978). Studies on the production and synthesis of pseudomonas protease are few. Morihara (1964) found that protease was produced in synthetic media containing $2 \%$ yeast extract; neither Liu (1974) nor S. Hesslewood and J. T. Smith (personal communication, 1979) could demonstrate the production of $P$. aeruginosa protease in completely synthetic media. The present study showed that the formation of protease in shake-flask TSB cultures occurred in the early stage of growth and increased during the logarithmic phase. This observation, together with the low levels of intracellular protease found, suggests that protease is an extracellular enzyme. Although protease produced by $P$. aeruginosa has been purified (Meinke $e$ t al., 1970), relatively little information is available on its site of synthesis, and on its subsequent release. Pollock's (1962) critical review on exoenzymes provides an admirable introduction to the difficulties inherent in the study of such problems. There is now strong evidence (Lampen, 1974) that exoenzymes originate from the cell without any alteration to cell structure. The inhibition of protease in the present study could be attributed to the inhibition either of synthesis or of release; the antibiotic had no effect on the activity of preformed protease. Tetracycline is known to inhibit protein synthesis by inhibiting the binding of amino acyl tRNA to the 30S units of bacterial ribosomes (Hash, 1972). Chloramphenicol, on the other hand, blocks the attachment of amino acids to the nascent peptide chain on the 50S unit of ribosomes by interfering with the action of peptidyl transferase. Polymyxin $B$ acts on the bacterial cell membrane, altering its permeability; there are two sites of action of polymyxin $B$, one (lethal) connected with the phospholipids in the inner membrane, and the other (non-lethal) connected with the lipopolysaccharides and phospholipids in the outer membrane of the bacterial envelope (Hash, 1972). It is difficult to explain protease inhibition in terms of the mode of action of the antibiotics used in our experiments. These antibiotics differed strikingly in their effect on protease production. The idea that extracellular products are synthesised or assembled on the surface of the cell membrane is attractive because many enzymes are known to be bound to the cell surface (Lampen, 1974). As a result of studies on Micrococcus sodonensis (Glew and Heath, 1971) and Bacillus amyloliquefaciens (Both et al., 1972), it was postulated that extracellular enzymes are synthesised at the cell membrane and are extruded through it.

Previous studies (Gemmell and Shibl, 1976; Shibl and Al-Sowaygh, 1979) with staphylococci and streptococci suggest that the site of synthesis of extracellular proteins is more peripherally situated or at least more accessible to the extracellular environment than is the site of synthesis of intracellular proteins. It is possible that membrane-bound ribosomes manufacture proteins that leave the cell, and that free ribosomes manufacture proteins that remain within it.

\section{SUMMARY}

The effects of tetracycline, chloramphenicol and polymyxin B on growth and protease production by Pseudomonas aeruginosa were studied. Tetracycline inhibited protease production at concentrations much lower than those required to cause growth inhibition; the effect was not due to inhibition of protease activity by the antibiotic. In contrast, chloramphenicol and polymyxin B inhibited protease production in direct proportion to the inhibition of growth. Lysozyme-release experiments with washed tetracycline-treated cells indicated that the protease did not accumulate intracellularly. The protease-inhibiting effect of tetracycline might have therapeutic significance if it were found to occur in vivo.

We are grateful to Professor J. T. Smith for critically reviewing the manuscript.

\section{REFERENCES}

Birdsell, D. C. AND Cota-Robles, E. H. 1967. Production and ultrastructure of lysozyme and ethylenediaminetetraacetate-lysozyme spheroplasts of Escherichia coli. J. Bact., 93, 427. 
Both, G. W., Mcinnes, J. L., Hanlon, J. E., May, B. K. and Elliott, W. H. 1972. Evidence for an accumulation of messenger RNA specific for extracellular protease and its relevance to the mechanism of enzyme secretion in bacteria. J. molec. Biol., 67, 199.

Brown, M. R. W. AND Foster, J. H. S. 1970. A simple diagnostic milk medium for Pseudomonas aeruginosa. J. clin. Path., 23, 172.

Buchanan, R. E. AND GibBons, N. F., (editors). 1974. Bergey's Manual of determinative bacteriology, 8th ed. Williams \& Wilkins: Baltimore.

BURTON, K. 1956. A study of the conditions and mechanism of the diphenylamine reaction for the colorimetric estimation of deoxyribonucleic acid. Biochem. J., 62, 315 .

Gemmell C. G. AND Shibl, A. 1976. Regulation of the production of toxins and enzymes by Staphylococcus aureus using antibiotics. Proceedings 8th meeting North West European Microbiological Group, Helsinki, p. 89.

Glew, R. H. AND Heath, E. C. 1971. Studies on the extracellular alkaline phosphatase of Micrococcus sodonensis. II. Factors affecting secretion. J. biol. Chem., 246, 1566.

GRAY, L. AND KREGER, A. 1979. Microscopic characterization of rabbit lung damage produced by Pseudomonas aeruginosa proteases. Infect. Immun., 23, 150.

HaSh, J. H. 1972. Antibiotic mechanisms. Ann. Rev. Pharmac., 12, 35.

Homma, J. Y., Tomiyama, T., Sano, H., Hirao, Y. and Saku, K. 1975. Passive hemagglutination reaction test using formalinized sheep erythrocytes treated with tannic acid and coated with protease or elastase of Pseudomonas aeruginosa. Jap. J. exp. Med., 45, 361.

LAMPEN, J. O. 1974. Movement of extracellular enzymes across cell membranes. Symp. Soc. exp. Biol., 28, 351 .

LiU, P. V. 1974. Extracellular toxins of Pseudomonas aeruginosa. J. infect. Dis., 130, suppl. S94.

LiU, P. V., ABE, Y. AND Bates, J. L. 1961. The roles of various fractions of Pseudomonas aeruginosa in its pathogenesis. J. infect. Dis., 108, 218.

Meinke, G., Barum, J., Rosenberg, B. AND BERK, R. 1970. In vivo studies with the partially purified protease (elastase) from Pseudomonas aeruginosa. Infect. Immun., 2, 583.

Morihara, K. 1964. Production of elastase and proteinase by Pseudomonas aeruginosa. J. Bact., 88, 745 .

Pollock, M. R. 1962. Exoenzymes. In The bacteria, vol. IV, edited by I. C. Gunsalus and R. Y. Stanier. Academic Press: New York, p. 121.

Shibl A. M. AND AL-Sowaygh, I. A. 1979. Differential inhibition of bacterial growth and hemolysin production by lincosamide antibiotics. J. Bact., 137, 1022.

Shimizu, T., Homma, J. Y., Aoyama, T., Onodera, T. and Noda, H. 1974. Virulence of Pseudomonas aeruginosa and spontaneous spread of pseudomonas pneumonia in a mink ranch. Infect. Immun., 10, 16.

WRETLIND, B. AND KRONEVI, T. 1978. Experimental infections with protease-deficient mutants of Pseudomonas aeruginosa in mice. J. med. Microbiol., 11, 145. 